\title{
IRISH FILM AND MEDIA STUDIES PUBLICATIONS
}

\author{
THE YEAR IN REVIEW - 2017
}

Ruth Barton (ed.)

Copyright (c) 2018 by the authors. This text may be archived and redistributed both in electronic form and in hard copy, provided that the author and journal are properly cited and no fee is charged for access.

\section{Introduction}

Ruth Barton

New Perspectives on Irish TV Series

Flore Coulouma, ed.

Ruth Barton 230

Irlanda y los irlandeses en el cine popular (1910-1970)

Carlos Menéndez Otero

E. Guillermo Iglesias-Díaz 
Introduction: 2017 - The Year in Irish Film and Media Publications

\section{Ruth Barton}

Another year has come and gone with little academic writing to show for Film and Media studies. I do appreciate that very interesting scholarly work on these topics is appearing in journals and collected editions. A search for "Irish cinema" in FIAF, for example, produced a listing of seventy results in the period 2010-2019. Interestingly, however, the bar chart peaks in 2011 (22 records), up somewhat from 2010 (15 records), descends to 13 records in 2012, to 10 records in 2013, to one record in 2014 (which seems to have minimal connection with Irish cinema anyway), a surge to five (very relevant) records in 2015, sliding back to one in 2016, (an article in Variety in a Special Supplement on Irish cinema that was presumably paid for), and three in 2016 - two trade journal articles and an essay on Monty Python. FIAF doesn't include chapters in Readers and its databasing of trade journals slightly skews the numbers. EBSCO for instance only lists thirty-two articles for the period 1994-20, which seems a little ungenerous to me. Literature Online, which covers book chapters and monographs as well as journal articles, lists 151 results, though these go back to the 1980 s and regrettably don't include search fields to narrow by date.

To return to the FIAF search, it does seem that the decline in book-length publications mirrors an overall drop in scholarly research in this field. However, I would like to believe it is a blip rather than a trend. For all those reasons, I am not giving up on this section, but I am suspending it. With luck Irish film and media studies will soon welcome a gaggle of new babies into the world of academic publishing and it will be 2011 all over again.

Ruth Barton is Associate Professor in Film Studies at Trinity College Dublin. She is the author of a number of publications on Irish cinema including Irish National Cinema (Routledge, 2004) and Acting Irish in Hollywood (Irish Academic Press, 2006). She has written critical biographies of the Hollywood star, Hedy Lamarr: Hedy Lamarr, The Most Beautiful Woman in Film (University Press of Kentucky, 2010) and the Irish silent era director, Rex Ingram: Rex Ingram, Visionary Director of the Silent Screen (University Press of Kentucky, 2014). She is currently preparing a new monograph on Irish cinema, Irish Cinema in the Twenty-First Century, for Manchester University Press.

bartonr@tcd.ie

New Perspectives on Irish TV Series

Edited by Flore Coulouma.

Oxford, Bern, etc.: Peter Lang, 2016. 216 pp.

ISBN: 9783034319775

Reviewer: Ruth Barton (Trinity College Dublin, Ireland)

Subtitled "Identity and Nostalgia on the Small Screen", Flore Coulouma's reader on Irish television series might just as well have included some reference to the Celtic Tiger and its aftermath on its front cover. This is very much a zeitgeist collection, and barely a contributor fails to reference the new Irish society of the boom years or the crash in public confidence 
when the end came. It is, in this way, a timely collection of essays and fills a useful gap in Irish television studies. Not all the essays cover recent productions; in fact, the opening essay by Sylvie Mikowski is devoted to the four-part series, Family, scripted by Roddy Doyle and first broadcast in 1994. She interestingly locates this within the British social realist/documentary tradition, an influence contingent upon the choice of Michael Winterbottom as director. Where it departs, she argues, from that model is that the series does not propose any cultural resistance in the shape of an authentic working-class culture. Just what she intends by the term "authentic" is not quite clear since she also refers to Ballymun as a symbol of the forgotten, marginalized Irish working-class. Perhaps it is more the notion of resistance that is most useful as an argument here. Certainly, Doyle's tone shifts considerably in this series from his earlier "Barrytown Trilogy", with its celebration of working class resilience in the face of circumstances not of their own making, to an image of marginalised suburban identities, whose ability to fight back, or even to form a cohesive community, is negligible such is their abjection.

Mikowski discusses Family as exemplifying a "form of dark naturalism" (23) which she traces back to writers of the twentieth century from George Moore and James Joyce through John McGahern and Dermot Bolger. This project, of debunking the myth of the "poor but happy" Irish is shared by a number of television productions discussed in New Perspectives on Irish TV Series. Thus, Sheamus Sweeney turns his attention to Prosperity, the four-part series written by Mark O'Halloran and directed by Lenny Abrahamson which was broadcast on RTÉ in 2007. A day-in-the-life of Dublin told from the perspective of four different characters, Sweeney is right to bemoan RTÉ's neglect to publish this on DVD or any other accessible format, a complaint that could be applied across the board, and certainly has hampered the development of Irish television studies. Since then, Prosperity has circulated as kind of samizdat offering, in exchange perhaps for some other jewel from RTÉ's past, like $A$ Week In the Life of Martin Cluxton (RTÉ, 1971). Indeed, placing those two side-by-side would provide an interesting commentary on the relationship between RTÉ's programme makers then and now. Sweeney too considers the influence of British social realism on contemporary productions, arguing that Prosperity benefits from its makers' lack of didacticism, and its refusal to act as a vehicle for social transformation. In particular, he notes how the series refuses to demonise the authority figures who stand in for the (invisible) state apparatuses but also refuses to embrace the neo-liberal position of blaming the poor for their poverty. If there is one overarching point to be taken from Prosperity, then, it is that poverty infantilises those who are caught in it.

If Family and Prosperity are productions that are clearly informed by a desire to investigate social disadvantage through fictional forms, then other RTÉ series are more evidently escapist in their audience appeal. Deirdre Quinn, for instance, discusses the popular police procedural, Single-Handed (RTÉ, 2007-2010), which was broadcast in the period from the end of the Celtic Tiger, through early austerity; while Catherine Conan looks at the Quirke adaptations (BBC, 2014). Both are very different and the critical fate of Quirke was rightly derisory. Single-Handed, on the other hand, was well-acted, scripted and shot, with the kind of remote rural setting that has been productive ground for detective fiction in the UK and elsewhere and the forum for examining an older culture of secretive dealings. The series drew its inspiration from the revelations of Garda corruption in Donegal and is focused on the repressions of Irish rural life that emerge in a series of criminal investigations. In season one ("Natural Justice"), Quinn writes, "the complicities of communities and close family members in concealing instances of abuse" form a consistent narrative thread. "It also examines a layer of society that was largely unseen until scandals surrounding the sexual and physical abuse of children in the care of both the Catholic Church and the State emerged in the 1990s" (76-77). What is interesting about the series, is Quinn's assertion that the past 
"unleashes the potential to undo the present" (79). The accusation so often levelled at films about the Irish past, The Magdalene Sisters (Peter Mullan, 2002), for instance, is that their narrative closure affirms the pastness of the past. This leaves the viewer in a safe place, at a distant remove from an old history of Irishness that is no longer part of their world, particularly the world of the Celtic Tiger. Single-Handed instead insists that little has changed in the present, which is as corrupt, if in a different way, to that older Ireland. Indeed, little can change in a rural Ireland insulated from outsiders. Benjamin Black's (aka John Banville) period detective thrillers, from which Quirke was adapted, were, on the other hand, written in the Celtic Tiger years but made in the post-Celtic Tiger era. The question that this raises for Conan is whether the subversive power of noir can survive the re-mediations of the contemporary TV series. These remediations, she argues, allow for the foregrounding of a specific Irish obsession over questions of paternity and filiation. I am not so sure just how specific to Ireland these questions really are, and there is a danger of drawing overarching conclusions about national identity from a very flimsy text that in turn found little favour locally. However, Conan makes interesting, if broad claims for Quirke as speaking to social discourses in post-De Valera Ireland around paternal legitimacy, and post-Crash society's collective guilt following the sexual abuse revelations. Reflections on the culture of violence in Irish society are also the topic of Flore Coulouma's analysis of Love/Hate (RTÉ, 2010-14). She argues that the popular series allowed for Irish audiences to understand violence in the relational context of post-capitalist societies and global TV series such as The Wire (HBO, 2002-08).Thus Nidge (Tom Vaughan-Lawlor) and his fellow gangsters model themselves on American gangsters. Yet the series retains its sense of the local both through place and accent, but also through its being part of a tradition that includes The General (John Boorman, 1998), and (she might have mentioned), older Irish films such as The Courier (Frank Deasy, Joe Lee, 1988). Coulouma's analysis of recent Irish television's project as reflecting on the fundamental rottenness of Irish society is one she shares with the majority of this volume's contributors.

Another thread running through this collection is the question of how contemporary entertainment productions deal with older national stereotypes. In his essay on The Savage Eye (RTÉ, 2009-2014), Thierry Robin considers how David McSavage (aka David Andrews jnr.) its co-creator and star, tears into a series of recognisable Irish types - the priest, the politician, the rural publican - with scant regard for political correctness or the sensitivities of the television audience. Nor does it spare national treasures, such as Mary Robinson, Pat Kenny and Joe Duffy, the latter consistently portrayed as being aroused by the misery stories related by members of the public on his hugely popular confessional phone-in radio show. Yet, under this display of anarchy, Robin astutely notes: "the series is actually driven by a highly moralizing political agenda denouncing corruption, sleaze, incoherence, superficiality, hypocrisy, intolerance - e.g. homophobia, racism, bigotry, sectarianism, chauvinism. As usual with satire, the transgression on the surface hides a craving for order at a deeper level" (98). Still, the series reflects on many of the new formations of the Celtic Tiger era, most notably the reversal of fate that sees the Irish, once the victims of racism, now proved to be racist themselves. Thus, old stereotypes are replaced with new and the series usefully draws attention to the anxieties of the new post-Celtic, post-Capitalist, post-Catholic Ireland around questions of national identity and belonging.

The theme of nostalgia promised in the book's sub-title emerges in relation to one particular series, Moone Boy (Sky One, 2012-15). Based on actor Chris O'Dowd's personal recollections of growing up in small-town Ireland, the series was hugely popular both in Ireland and overseas. Anthony McIntyre analyses Moone Boy as informed by O'Dowd's "down home" persona and his distance from the hedonistic excesses of Celtic Tiger-era stars such as Colin Farrell and Jonathan Rhys Meyers. This is then located within a space (small- 
town Ireland) and time (the late 1980s) before the country was transformed by the boom economy. The kind of nostalgia evoked by this reinvention of an Ireland of simpler times, McIntyre convincingly argues, speaks to an attempt to "shore up a fractious present through recourse to a more optimistic past" (145). In this happy past, the Moone family's relative poverty brought them together rather than destroying them as it might have in a series set in post-Celtic Tiger Ireland. Yet, at the same time, as he argues, the series speaks to male anxieties around the erosion of authority during the recession (or mancession, if you must). Where it allows for a reading as a progressive text is in its refusal to render weird the youngsters' playful attitude to conventional masculine roles.

Several of the series analysed in this collection are literary adaptations and the book ends with Ruth Lysaght's analysis of three short Irish-language adaptations for Irish-language broadcaster, TG4. Unusually for this volume, the past here is seen not as the bearer of unspeakable histories but as a repository of cultural riches, heretofore buried as a consequence of the minority status of the Irish language in which the original stories were written. What Lysaght's essay does have in common with the other contributions is a light theoretical touch. It is interesting how little existing theoretical (as opposed to historical) work exists on Irish television for these contributors to draw on and develop, which in turn points to the underdevelopment of Irish television studies as a discipline. This very useful reader goes some considerable way to righting this and one hopes will inspire others to follow. It is also to be hoped that future generations of Irish television scholars will have at their disposal greater access to Irish programme making than is currently the situation, and which will allow this emerging discipline to take its place amongst other national television studies.

Ruth Barton is Associate Professor in Film Studies at Trinity College Dublin. She is the author of a number of publications on Irish cinema including Irish National Cinema (Routledge, 2004) and Acting Irish in Hollywood (Irish Academic Press, 2006). She has written critical biographies of the Hollywood star, Hedy Lamarr: Hedy Lamarr, The Most Beautiful Woman in Film (University Press of Kentucky, 2010) and the Irish silent era director, Rex Ingram: Rex Ingram, Visionary Director of the Silent Screen (University Press of Kentucky, 2014). She is currently preparing a new monograph on Irish cinema, Irish Cinema in the Twenty-First Century, for Manchester University Press.

bartonr@tcd.ie

Irlanda y los irlandeses en el cine popular (1910-1970)

Carlos Menéndez Otero.

Salamanca: Amarante, 2015. 248 pp.

ISBN: 9788494623721

\section{Reviewer: E. Guillermo Iglesias-Díaz (UNIR - International University of La Rioja, Spain)}

From popular music to academia or the appearance in theatres of The Rebel (a musical about Pádraig Pearse), increasing interest about Ireland in Spain is evident and the publication of a book in Spanish dedicated to the representation of the Irish in film should be a matter of celebration (in particular, for researchers in film and Ireland). Nevertheless, Irlanda y los Irlandeses en el Cine Popular (1910-1970) leaves the reader with mixed emotions: it is true 
that the style is straightforward and easy to read; the documentation work is outstanding and the profusion of film titles is, on occasion, overwhelming; and it cannot be denied either that there are glimmers of sharp analysis dotting the pages here and there. However, after reaching the end of the book, one has the feeling of the missed opportunity, the lost chance of going beyond the mere informational to offer a deep analysis of thought-provoking issues about the Irish diaspora in the US, from its relation with the homeland or its decisive role in the construction of Ireland as the nation that it is today, to the influence of Hollywood (understood as industry) in that construction, or the stereotypical gender roles (both male and female) when depicting the Irish, just to mention but a few of the wide range of possibilities. Thus, even though most of these issues are addressed, the approach is fragmentary, often superficial and in most occasions boiling down to just a description of sequences and plots.

The fact that the content is organized following the chronology in the title contributes to the fragmentation and dispersion of arguments and if, for instance, the author introduces the treatment of Irish female roles in film, we see sporadic (and too brief) comments depending on the film or the decade dealt with in that particular section. Just to offer but one example, stereotyping is tackled throughout the book: one of the first examples is the reference to clichés in film and theatre (22), though there is no further analysis about the origin or purpose of such stereotyping, who and why propagated it and how it affected the Irish community. On page 72, the author includes a good analysis about the WASP stereotype of the drunken, lazy Irishman, permanently living with nostalgia for their lost homeland. However, Menéndez does not explore the implications of the stereotype, what those portrayals meant at the time in US society, or the "coincidence" with a long literary tradition in British colonial culture. Moreover, there are references to ready-made tropes in terms of the setting, with the classic opposition between an idealized community of rural bliss as opposed to urban decadence presented as the space for violent turmoil. Once more, the author fails to identify these oppositions as part of a discourse imposed by a colonial literary tradition that places the Irish at a far remove from modernity and civilization.

Before focusing on some specific issues, a last comment on the organization and content of the book should be noted: if we take into account the time lapse setting the limits of the field of analysis, the reader will notice the inclusion of films which go well beyond 1970s in the last section, dedicated to films of the post-classic era. Menéndez includes some titles connected somehow to the films in the 1950s and 1960s dealing with Irish folklore (165) but, surprisingly, no mention is made to, arguably, the two living and most popular Irish filmmakers since the 1980s, Jim Sheridan and Neil Jordan, an absence that is perhaps related to the author's conception of "politicization" in film representations about Ireland.

In this sense, it is shocking the way in which the term "politicization" is used, to refer exclusively to those films in which the story deals with explicit political issues. For example, there is a simplistic reference of this kind (26) about the "politicization" of the historical melodrama just because of the presence of "nationalist topics" in a film such as Shamus $O$ ' Brien: if nationalism or "politics" were ignored at the beginning of the twentieth century in the representation of Ireland in film, maybe another kind of politics was being carried out, that of silencing a people who were demanding deep changes in their country and fighting British colonial rule. In this respect, there is another instance (106-8) when the film Parnell (John M. Stahl, 1937) is discussed and the historical figure is described as somebody who "was never a revolutionary or a secessionist, but a clever political strategist who unified and consolidated Irish nationalism" (my translation) and somebody who knew how to take to the British Parliament "some of the reforms about land distribution and political autonomy which had fueled traditionally the violence in Ireland" (my translation), a statement which, in my opinion, falls short if we want to offer a rigorous analysis to explain decades of violence before and after independence. The author fails to acknowledge the difference between a 
hegemonic nationalism (as was the case after independence) and one of resistance and opposition to colonial rule. And these are but two examples of several which can be found throughout the pages of the book: just to offer one more, in page 60 we find probably the most questionable statement about "politics", when immigrants to the US in the $19^{\text {th }}$ century are described as "politicized", leaving the reader wondering how you can avoid politicization when your country is living under colonial rule and you are aware of your good luck for escaping death during the Great Famine and surviving the (in)famous coffin ships. This politicized Irish community gave way to a new generation who, according to the author, in the first decades of the $20^{\text {th }}$ century started being "accepted" by the hegemonic WASP society, another questionable way of putting the issue.

Menéndez states that this gradual process of acceptance started as early as the 1920s, though there are plenty of examples contradicting this hypothesis, for instance, the campaign by the Republicans against the Democrat candidate to mayor's office in New York just because he was a Catholic (as the very same author admits in page 45) or, decades later, in the 1960s, when J.F. Kennedy had to face similar prejudices. Nevertheless, Menéndez points out that it was in that decade at the beginning of the $20^{\text {th }}$ century when films about the Irish diaspora in the US started including characters of Irish descent moving up the social ladder. However, there is no further explanation or comment as to how and why in this particular decade the Irish community gradually started being considered part of the "founders of the nation" beyond the suggestion that it was the WASPs who welcomed the Irish after some decades of mutual distrust $(9,79,80-1,95,126)$. Such examples include Little Old New York (Olcott, 1923), about a rich Irish immigrant living in the first decades of the $19^{\text {th }}$ century, and John Ford's The Iron Horse (1925), about the Irish workforce in the construction of the transcontinental railway. What I find particularly interesting is that Menéndez also mentions films (such as Whitewashed Walls or Fortune's Mask) where Americans of Irish descent are represented as supporters of the Monroe doctrine that justified an aggressive imperialist attitude of the USA in the continent from Cuba to Nicaragua, Haiti or Dominican Republic (44). However, the author fails to link explicitly the acceptance by US hegemony of the Irish on condition they adopt their most conservative values, appointing them to the role of keepers of the American essence, that is, the heteropatriarchal family, (white) American nationalism and (Christian) religion as the basic foundations of society.

On the other hand, bearing in mind that the scope of the book reaches 1970, it is hardly surprising that the bulk of the work (134-158) focuses on that sort of black hole of Irish film culture we are all irremediably drawn to, known as The Quiet Man (1952) and John Ford's masterpiece about his forebears' homeland. Menéndez does not hide his keenness on the film and transmits his enthusiasm in the analysis he carries out in, possibly, the best part of the book: he introduces the film by framing it in that sub-genre called "outsider narrative", and it is the first time that a connection is explicitly established between popular films and ideology, describing how the colonial narratives about Ireland always put the blame for the wrongs of Ireland on the shoulders of the Irish (and their natural tendency to irrationality and violence), on the extreme climate or on the wild landscape that in turn exerted a bad influence on the Irish character. However, despite mention of the concept of "self-exoticism" (128), the author never addresses the implications of the term and how problematic it may be when applied to Ford (141): once again, some deeper analysis about national identity and diasporic communities is missed. Moreover, the author never makes a reference to the influence of the (Irish) diaspora in the construction of (Irish) national identity or, more in particular, the decisive role of (literary or cinematographic) narration in the construction of a collective identity, as many specialists have pointed out since, at least, the late 80s.

In this sense, the question of "authenticity" and "reality" glides over the work, but Menéndez never seems to challenge the concept and, although he includes several references 
to the metanarrativity in Ford's film (140), he insists on opposing the imaginary Ireland in the film to a "real" Ireland that exists, we understand, beyond the filmic frame. Furthermore, the imaginary Ireland seems to exist exclusively in the nostalgic memories of the diasporic Irish, as if Ireland were not an "imagined community" itself. On the other hand, if metanarrative devices are used to underscore the discursive nature of the narration, they also blur the "fiction/reality" divide: as Patricia Waugh stated some decades ago, those formal and narrative resources establish a parallelism between the reality inside the film and the reality outside, as in both cases it is a reality that exists because of (narrative, social) conventions.

Dealing with conventions and The Quiet Man it is impossible not to address the role of Maureen O'Hara playing Mary Kate. There are plenty of references to the role of women in film, mostly as femme fatales, mothers and/or colleens (85-6) but the analysis is merely descriptive and there is no further comment about those patriarchal constructions or the fact that they have features in common with other national cultures, from Spain to India, with the female body as idealized or belittled, but always objectified and subaltern to the male. There is a reference (145) to the idealization of Mary Kate (in parallel to rural Ireland) in the first scene, but without any further comment about the well-known patriarchal strategy of glorifying the female body just to keep it under control and this is but one example to the kind of descriptive analysis Menéndez offers: in page 149, for instance, he describes the scene in which Mary Kate cleans the house, lights the fire and Sean "steals" two kisses from her, but again, the analysis just stops there.

The analysis of Mary Kate is carried out by contextualizing the role in Maureen O'Hara's career, comparing her with other female archetypes in some other classic narratives (Katherina in Shakespeare's The Taming of the Shrew, or Eve and Mary in the Bible). All in all, the author does not comment on the actual portrayal of Mary Kate in the film. Any criticism as to the explicit sexism in the film is attributed to the patriarchal society in which the film was produced (excusing somehow Ford's open sexism) and how O'Hara was used to promote a role-model that could still be "the object of the male gaze" and, at the same time, "channel her rebelliousness and strength" towards the economic recovery after WWII (14950) (my translation). Of course, as we know, both O'Hara's and Mary Kate's is a controlled rebelliousness although, once more, Menéndez seems to ignore it and discusses the "symbolic taming" of the red-haired shrew, a fact that only occurs when Thornton recovers his "Irish masculinity" (whatever that means though, I'm afraid, it is nothing good...) and leaves behind his "anglicized" self: at this moment, following the interpretation of the author, Mary Kate does not need to rebel any more (152). I must say I would rather have a more complete analysis of what we actually have in the film as, for instance, that sequence that still provokes angry reactions in feminist quarters (despite the "ironic distance") when Thornton picks up a stick which, significantly, an old woman (as embodiment of tradition) gives him and treats Mary Kate as a cow. According to the author, if Mary Kate was introduced as a little shepherdess in an idyllic rural setting at the beginning, now it is Sean's turn to be introduced as a "symbolic shepherd" who will tame the shrew into the "Irish-community flock" [sic] at the same time as he becomes part of that community by means of a "violent and at the same time festive ritual..." (155). There is no interpretation of the sequence or the implications of the portrayal of these forever ex-centric Irish people, just a description (more or less accurate) of what we see on the screen. Actually, maybe that ironic distance set by Ford is not appreciated by the wider public and since its release the film has become a classic in the celebration of St. Patrick's Day in the US and, as the very same author acknowledges, after the film, thousands of American tourists have travelled to Ireland looking for the places where the action took place (157).

As a conclusion, I still believe that the publication of a book in Spanish about the Irish in film is to be celebrated, although Irlanda y los Irlandeses en el Cine Popular (1910-1970) 
does not fulfill the expectations: the general impression is that the author includes too many titles and film plots, but the analysis in most occasions is fragmentary (due to the organization of the content into decades) and superficial, also because of the great amounts of topics he tries to deal with. Paradoxically, many other issues are left out, from the construction of a national identity and the influence of the cinematographic narration in that construction, to the relation between the Irish diaspora and the homeland, and the role of the Irish community in the United States.

E. Guillermo Iglesias-Díaz works as a lecturer at UNIR (Universidad Internacional de La Rioja) and is a member of the research group "BIFEGA: Cultural and Literary Studies, Translation and Interpretation" at the University of Vigo. He is currently a member of the research project "Bodies in Transit 2". His research focuses on the interaction between transmodernism and postcolonial theory in film, paying special attention to the role of cinema in European discourses on nationalism and gender constructions.

egid1@uvigo.es 